\title{
Dehio/Gall
}

\section{Handbuch der Deutschen}

\author{
Kunstdenkmäler
}

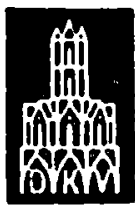




\title{
Georg Dehio
}

\section{Handbuch der Deutschen Kunstdenkmäler}

\author{
neu bearbeitet von \\ Ernst Gall
}


Ernst Gall

Handbuch der Deutschen Kunstdenkmäler Oberbayern

1952

Deutscher Kunstverlag München Berlin 



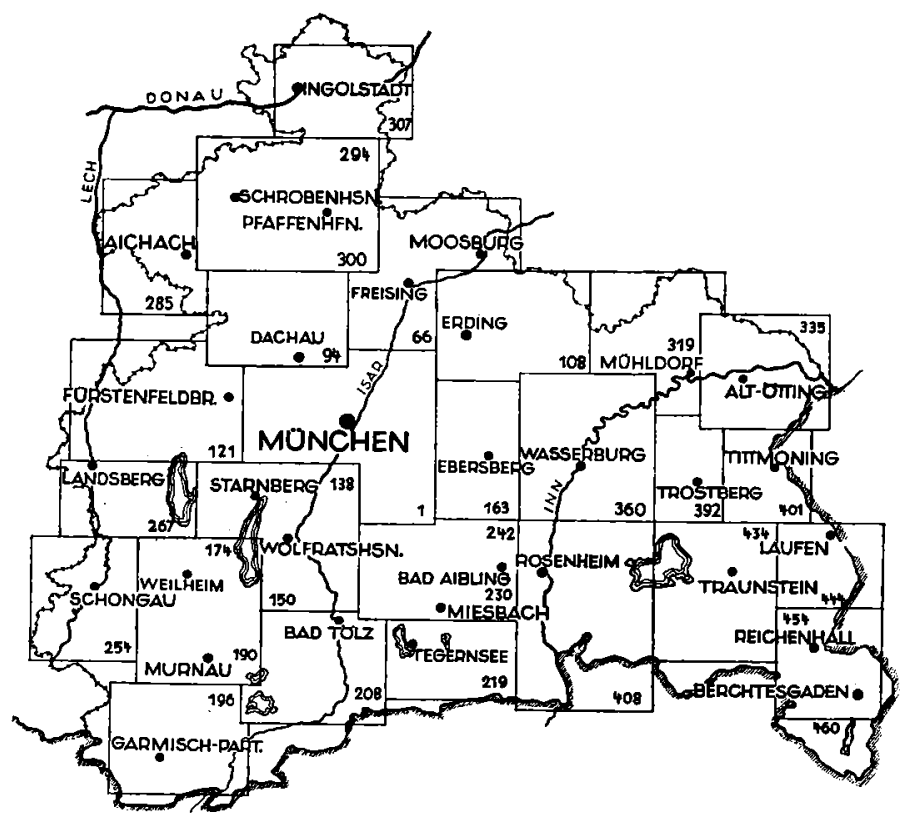

Die Zahlen in den Feldern verweisen auf die Textseiten

I N H A L T

München und Umgebung . . . . . . . . . . . . r

Das Münchener Umland: mittleres Oberbayern . . 66

Das westliche und nordwestliche Oberbayern . . . 254

Das östliche Oberbayern . . . . . . . . . . . 319

Künstlerverzeichnis . . . . . . . . . . . . . . 468

Ortsverzeichnis . . . . . . . . . . . . . . . 480 